\title{
PENERAPAN ANALISIS KONSEP NILAI HASIL DI PROYEK PEMBANGUNAN SARANA PRASARANA RADAR PASIF STT NATUNA DENGAN MENGGUNAKAN PROGRAM PRIMAVERA P6
}

\author{
Mohammad Farhan Alfathan ${ }^{1)}$, Setiono ${ }^{2)}$, Muji Rifai ${ }^{3)}$ \\ 1) Mahasiswa Fakultas Teknik, Prodi Teknik Sipil, Universitas Sebelas Maret \\ 2), 3) Pengajar Fakultas Teknik, Prodi Teknik Sipil, Universitas Sebelas Maret \\ J1. Ir. Sutami No. 36A, Kentingan, Surakarta 57126; Telp. (0271) 647069, Fax 634524 \\ Email: farhanalfathan.2403@student.uns.ac.id
}

\begin{abstract}
Earned Value analysis is the concept of calculating the amount of costs that will and have been incurred based on the performance of the work completed. By using the concept of earned value analysis, the results can be used as a control tool as a predictor of the cost and time of projects that have been implemented. This research was also conducted to determine whether or not the application of the concept of earned value analysis was effective as a performance evaluation for project implementation. This research was conducted in six stages, namely the preparation stage, the stage of determining the research object, the data collection stage, the data analysis and evaluation stage, the control stage, and the conclusion stage. At the data analysis stage, the use of the concept analysis of the results is carried out with the help of Primavera P6 software. The data used uses the data of the STT TNI Passive Radar Infrastructure Development Project which consists of the project implementation time schedule, RAB, and Project Progress Report (LAPJU). Data analysis was carried out based on pre-construction data and project weekly simulation reports provided. From the analysis conducted in the 8th week of the project, there is a prediction from the Primavera P6 program that the contractor will experience a project cost difference of $9.4979 \%$. the results that have been carried out, which indicate that the analysis of the concept of earned value for results is effectively used as a method of evaluating performance in project implementation.
\end{abstract}

Keywords: Earned Value, Primavera P6, Weekly Report

\begin{abstract}
Abstrak
Analisis konsep nilai hasil merupakan konsep menghitung besar biaya yang akan dan sudah dikeluarkan berdasarkan kinerja pekerjaan yang diselesaikan. Dengan menggunakan analisis konsep nilai hasil mampu menjadi alat kontrol sebagai prediksi besarnya biaya dan waktu proyek yang telah terlaksana. Penelitian ini juga dilakukan untuk mengetahui efektif atau tidaknya penerapan analisis konsep nilai hasil sebagai evaluasi kinerja untuk pelaksanaan proyek. Penelitian ini dilakukan dalam enam tahap yaitu tahap persiapan, tahap penentuan objek penelitian, tahap pengumpulan data, tahap analisis data dan evaluasi, tahap pengendalian, dan tahap kesimpulan. Pada tahap analis data penggunaan analisis konsep hasil dilakukan dengan bantuan software Primavera P6. Data yang digunakan menggunakan data Proyek Pembangunan Sarana Prasarana Radar Pasif STT TNI yang terdiri dari time schedule pelaksanaan proyek, RAB, dan simulasi Laporan Kemajuan Proyek (LAPJU). Analisis data dilakukan berdasarkan data pra-konstruksi dan simulasi laporan mingguan proyek yang diberikan. Dari analisis yang dilakukan pada minggu ke-8 proyek, terdapat prediksi dari program Primavera P6 bahwa kontraktor akan mengalami selisih biaya proyek sebesar 9,4979\%. Dari analisis yang dilakukan juga ditemukan besar simpangan atau perbedaan sebesar kurang dari 1\% terhadap analisis konsep nilai hasil yang telah dilakukan, yang mengindikasikan bahwa analisis konsep nilai hasil efektif digunakan sebagai metode evaluasi kinerja pada pelaksanaan proyek.
\end{abstract}

Kata Kunci : Earned V alue, Laporan Mingguan, Primavera P6

\section{PENDAHULUAN}

Indonesia merupakan salah satu negara berkembang (developing country), seperti lazimnya negara berkembang pekerjaan konstruksi akan semakin berlimpah setiap tahunnya. Hal ini didukung berdasarkan data dari Kementerian PUPR melalui Menteri Basuki Hadimuljono (2020) menginfomasikan bahwa anggaran infrastruktur yang dianggarkan oleh pemerintah pada tahun 2021 mencapai 149 Triliun. Dalam penyelenggaraanya, konstruksi membutuhkan pengelolaan yang baik dan benar, sehingga mampu mendapatkan hasil yang diinginkan. Untuk memperoleh hal tersebut, maka harus terbentuk sistem manajemen yang baik. Perkiraan hasil dapat bisa diketahui apabila sistem manajemen proyek dilaksanakan dengan baik dan benar.

Efisiensi dan efektifitas dalam pelaksanaan pekerjaan konstruksi dipengaruhi oleh beberapa faktor antara lain adalah perencanaan desain dan struktur yang matang, kebijakan di dalam proyek yang baik, kualitas sdm yang mempuni serta scheduling atau perencanaan penjadwalan. Perencanaan penjadwalan konstruksi dilakukan dengan tujuan agar dalam pelaksanaannya pekerjaan konstruksi menjadi lebih praktis dan lebih efektif sehingga tidak terjadi keadaan yang diakibatkan tertundanya pekerjaan karena tidak direncanakan dengan baik dan benar. Perencanaan penjadwalan juga merupakan satu faktor yang paling penting dalam keberlangsungan proyek, 
perencanaan penjadwalan yang baik akan mempengaruhi optimasi estimasi biaya yang sedang direncanakan. Hubungan antara kedua ini bisa dianalisis menggunakan metode konsep nilai hasil

Konsep earned value atau konsep analisis nilai hasil menurut Muhammad Izeul Maromi (2015) merupakan konsep menghitung besarnya biaya yang akan dan sudah dikeluarkan berdasarkan kinerja pekerjaan yang telah diselesaikan. Analisis nilai hasil dapat menghitung perbedaan biaya dan waktu saat pelaksanaan dibandingkan dengan saat perencanaan. Dengan menggunakan analisis nilai hasil juga mampu menjadi alat kontrol sebagai prediksi besarnya biaya dan waktu proyek yang telah terlaksana.

\section{DASAR TEORI}

\section{Proyek}

Proyek menurut Dedi Apriyanto (2016) didefinisikan sebagai kegiatan independen yang waktu dan sumber daya nya terbatas untuk bisa mencapai hasil akhir yang telah direncanakan. Didalam prosesnya mencapai hasil akhir, terdapat tiga batasan yang mutlak untuk terpenuhi. Ketiga batasan tersebut adalah besar biaya yang dialokasikan, jadwal, dan mutu yang merupakan parameter yang bersifat interdependen sehingga mempunyai sifat saling ketergantungan satu sama lain.

\section{Penjadwalan Proyek}

Penjadwalan proyek didalam buku Manajemen Proyek dari Konseptual sampai Operasional menurut Soeharto (1995) adalah pengaturan waktu yang tersedia untuk melaksanakan setiap pekerjaan dalam rangka menyelesaikan suatu proyek hingga tercapainya hasil yang diharapkan dengan mempertimbangkan beberapa batasan yang ada. Penjadwalan proyek secara garis besar berfungsi untuk mengatur urutan pekerjaan serta membagi waktu untuk seluruh pekerjaan atau kegiatan didalam proyek.

\section{Metode Konsep Nilai Hasil}

Didalam dunia konstruksi sistem pengelolaan yang digunakan akan memisahkan antara sistem biaya dan jadwal. Informasi manajemen proyek kedua sistem tersebut mempunyai sifat yang saling melengkapi tetapi dapat menghasilkan informasi yang tidak serupa mengenai status proyek. Konsep nilai hasil mampu mengintegrasikan sistem waktu dan sistem biaya menjadi sebuah kesatuan. Metode konsep nilai hasil menurut Soeharto (1995) dalam skripsi Rifqi Auzan N (2017) adalah konsep menghitung besarnya biaya menurut anggaran berdasarkan presentase pekerjaan yang sudah diselesaikan. Konsep tersebut dapat dilihat sebagaimana persamaan [1] berikut.

Nilai Hasil $=\%$ Penyelesaian $\mathrm{x}$ Anggaran [1]

Keterangan :

$\%$ Penyelesaian $=$ presentase penyelesaian pekerjaan yang dicapai

Anggaran = rencana anggaran biaya dari data pra-konstruksi proyek

Terdapat tiga indikator dalam analisa konsep nilai hasil, yaitu BCWS (Budgeted Cost of Work Schedule) merupakan anggaran biaya yang telah direncanakan berdasarkan jadwal pelaksanaan proyek, BCWP (Budgeted Cost of Work Performed) merupakan anggaran biaya dari seluruh pekerjaan yang sudah dilaksanakan sepanjang periode konstruksi, dan ACWP (Actual Cost Work Performed) merupakan biaya aktual yang telah dikeluarkan untuk penyelesaian pekerjaan pada periode waktu tertentu.

\section{Analisa Kinerja Proyek}

Dengan adanya ketiga indikator konsep nilai hasil, penulis dapat menghitung factor-faktor yang akan menunjukan kemajuan dari pelaksanaan proyek tersebut seperti CV (Cost V ariance) atau varians biaya terpadu sebagaimana persamaan [2] berikut.

$\mathrm{CV}=\mathrm{BCWP}-\mathrm{ACWP}$

Dengan adanya ketiga indikator konsep nilai hasil, penulis juga mampu menghitung SV (Schedule Variance) atau varians jadwal terpadu sebagaimana persamaan [3] berikut.

$\mathrm{SV}=\mathrm{BCWP}-\mathrm{BCWS}$ 
Ketiga indikator konsep nilai hasil juga mampu menghitung penggunaan sumber daya yang harus diinformasikan khususnya kepada pengelola proyek. Penggunaan sumber daya dapat dikemukakan sebagai indeks kinerja atau indeks produkivitas. Indeks produktivitas ini salah satunya adalah indeks kinerja biaya (CPI). sebagaimana persamaan [4] berikut.

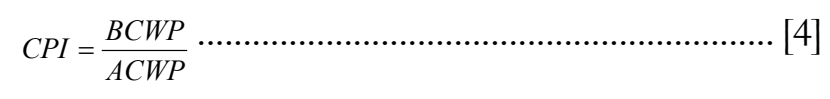

Indeks produktivitas ini juga terdiri dari indeks kinerja jadwal (SPI). sebagaimana persamaan [5] berikut.

$$
S P I=\frac{B C W P}{B C W S}
$$

\section{Proyeksi Pengeluaran Biaya}

Metode konsep nilai hasil mampu menunjukan berapa perkiraan biaya serta berapa lama jadwal penyelesaian proyek berdasarkan indikator indikator yang didapatkan sebelumnya. Petunjuk besarnya biaya pada akhir proyek atau BETC (Budgeting Estimate to Complete) Berikut persamaan [6] yang digunakan.

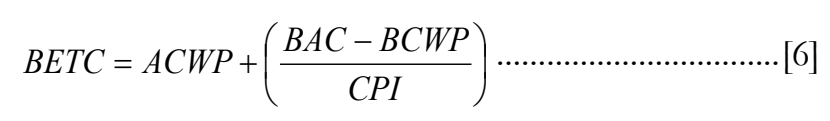

Keterangan :

$B A C=$ biaya proyek yang telah dianggarkan

Metode konsep nilai hasil juga mampu menunjukan perkiraan waktu yang dibutuhkan untuk menyelesaikan proyek atau SETC (Schedule Estimate to Complete) yang sangat bermanfaat karena sifatnya akan memperingati mengenai hal hal yang belum terjadi. Berikut persamaan [7] yang digunakan.

$$
S E T C=A T E+\left(O D-\frac{A T E-S P I}{S P I}\right) \cdots \cdots \cdots \cdots \cdots \cdots \cdots \cdots \cdots \cdots \cdots \cdots \cdots \cdots \cdots \cdots
$$

Keterangan :

$A T E$ = waktu yang telah ditempuh

OD = waktu yang direncanakan

\section{Aplikasi Program Primavera P6}

Pengelolaan proyek konstruksi dapat dikerjakan dengan lebih efektif menggunakan bantuan aplikasi Primavera P6 yang dikembangkan oleh perusahaan Oracle. Program Primavera mampu mengatur informasi proyek menggunakan kode-kode aktivitas, sumberdaya dan tanggal sebagai kerangka struktural, serta mempunyai fitur yang lebih baik di pengontrolan biaya dan sumberdaya. Program Primavera dapat diatur output nya sehingga mampu menjadi program pendukung dalam melakukan analisis konsep nilai hasil.

\section{METODE PENELITIAN}

\section{Pengumpulan Data}

Analisis ini digunakan penulis dengan mengambil contoh studi kasus yaitu Proyek Pembangunan Sarana Prasarana Radar Pasif di STT Natuna. Untuk mempermudah analisis didalam skripsi ini diperlukan data-data yang berkaitan langsung dengan proyek tersebut. Data-data yang akan digunakan adalah:

1. Time Schedule pelaksanaan proyek,

2. Rencana Anggaran Biaya (RAB),

3. Simulasi Laporan Kemajuan Proyek (LAPJU).

\section{Analisis Data}

Program Primavera P6 digunakan sebagai bantuan untuk penulis melakukan analisis data. Dengan program Primavera P6 penulis akan menginputkan semua data terkait sebagai upaya untuk melakukan analisis ke dalam program, selanjutnya program akan melaksanakan perhitungan secara otomatis sesuai dengan rumus-rumus kalkulasi 
yang berada di program tersebut. Hasil yang akan di peroleh dari analisis tersebut adalah besarnya SV (Schedule Variance), CV (Cost V ariance), CPI (Cost Performance Index), dan SPI (Schedule Performance Index) yang bisa digunakan sebagai nilai serta dapat diketahui apakah terjadi penyimpangan atau tidak. Analisis ini juga akan memperoleh proyeksi besarnya perkiraan biaya yang harus dikeluarkan serta berapa lama waktu yang dibutuhkan untuk menyelesaikan penyelesaian proyek. Proses penginputan data akan melalui dua tahap, yaitu:

1. Penyusunan rencana jadwal serta penyusunan biaya proyek

2. Tracking aktualisasi data lapangan

\section{HASIL DAN PEMBAHASAN}

\section{Indikator Konsep Nilai Hasil pada Minggu ke-4}

Dari hasil analisis data yang dilakukan didalam program Primavera P6 diperoleh indikator-indikator konsep nilai hasil yang didapat dari Laporan Proyek Pembangunan Sarana Prasarana Radar Pasif STT Natuna pada minggu ke4. Hasil ini dapat dilihat pada gambar 1

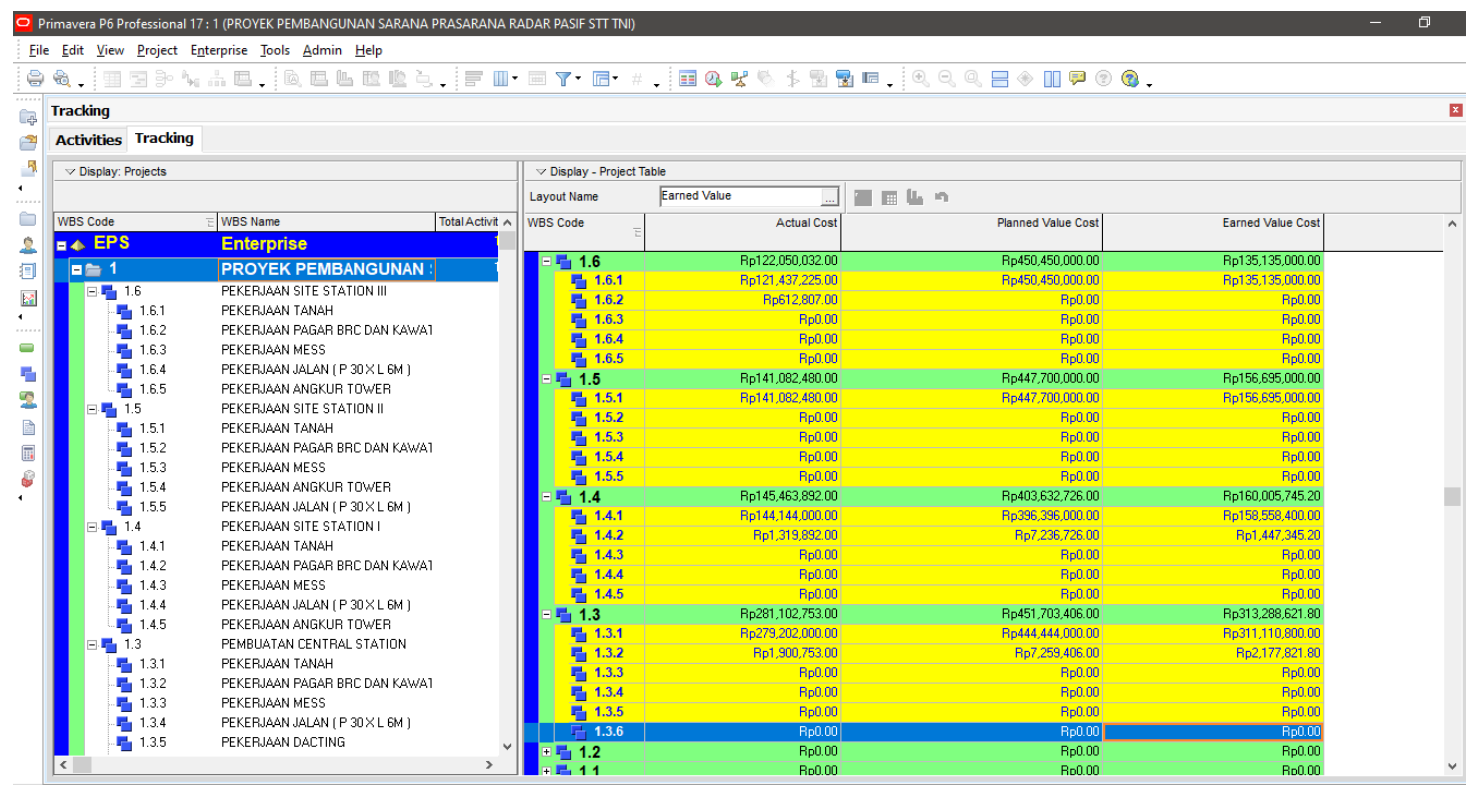

Gambar 1. Hasil indikator konsep nilai hasil pada minggu ke-4

Dari hasil analisis data yang dilakukan di dalam program Primavera P6, diperoleh indikator-indikator konsep nilai hasil yang didapat dari Laporan Proyek Pembangunan Sarana Prasarana Radar Pasif STT Natuna pada minggu ke4. Indikator-indikator tersebut adalah Actual Cost merupakan data pengeluaran di lapangan pada saat pelaporan pekerjaan, Planned V alue Cost merupakan data RAB pada pekerjaan dan Earned Value merupakan nilai hasil yang didapatkan berdasarkan kinerja setiap aktivitas. Berdasarkan ketiga indikator konsep nilai hasil, didalam aplikasi Primavera P6 diperoleh kinerja pelaksanaan proyek yang ditunjukan pada Gambar 2 berikut. 


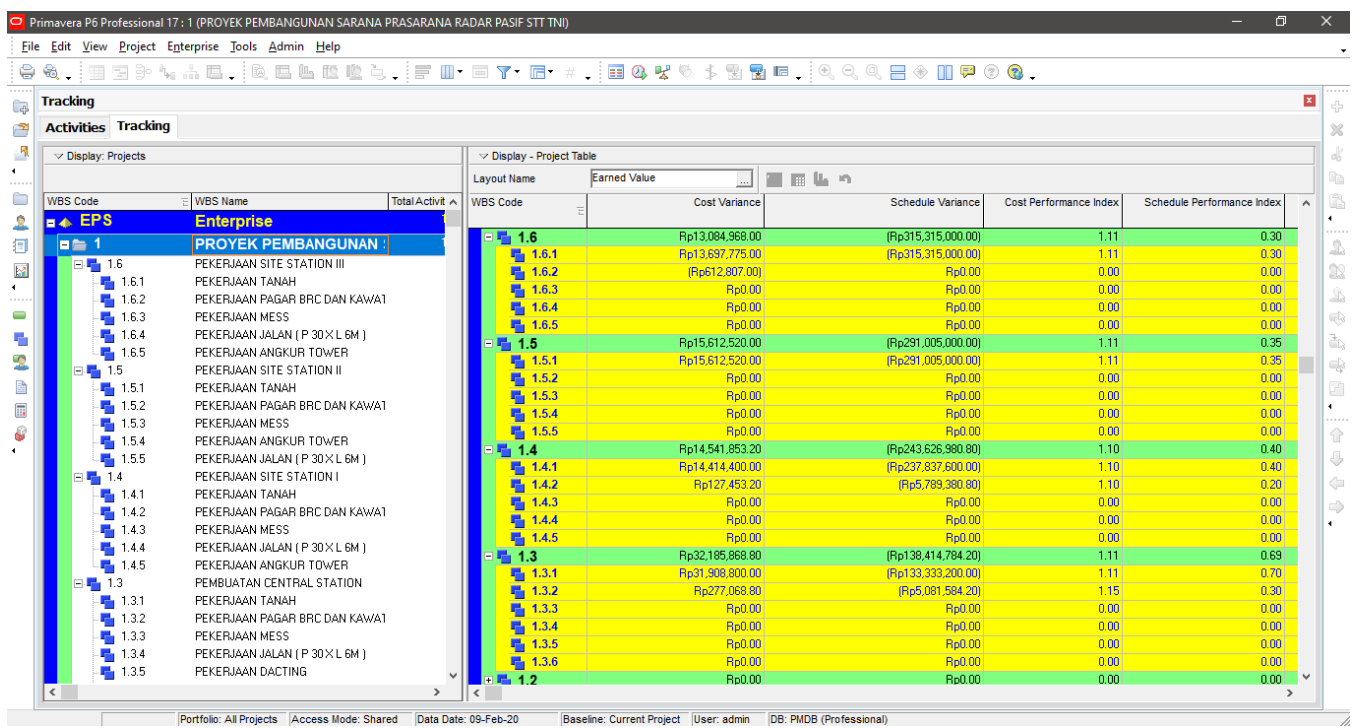

Gambar 2. Tracking kinerja pelaksanaan pada minggu ke-4

Hasil didalam program menunjukkan bahwa pada setiap item pekerjaan nilai dari ACWP lebih kecil dari BCWP atau Earned Value, yang berarti sampai minggu ke-4 biaya yang telah dikeluarkan proyek lebih kecil dari anggaran, hal ini juga terlihat didalam besarnya Cost Variance (CV) yang nilainya positif dan dengan besaran Cost Performance Index (CPI) lebih besar dari satu. Sedangkan terlihat pada segi waktu pelaksanaan, angka BCWP atau Earned Value lebih kecil daripada BCWS, yang mengindikasikan bahwa proyek berjalan lebih lambat dari jadwal yang direncanakan. Hal ini didukung dengan nilai Schedule Performance Index (SPI) yang kurang dari satu dan Schedule V ariance (SV) yang bernilai negatif.

\section{Indikator Konsep Nilai Hasil pada Minggu ke-8}

Dari Primavera P6 diperoleh indikator-indikator konsep nilai hasil yang didapat dari analisis data menggunakan Laporan Proyek Pembangunan Sarana Prasarana Radar Pasif ST'T Natuna pada minggu ke-8. Hasil ini dapat dilihat pada gambar 3

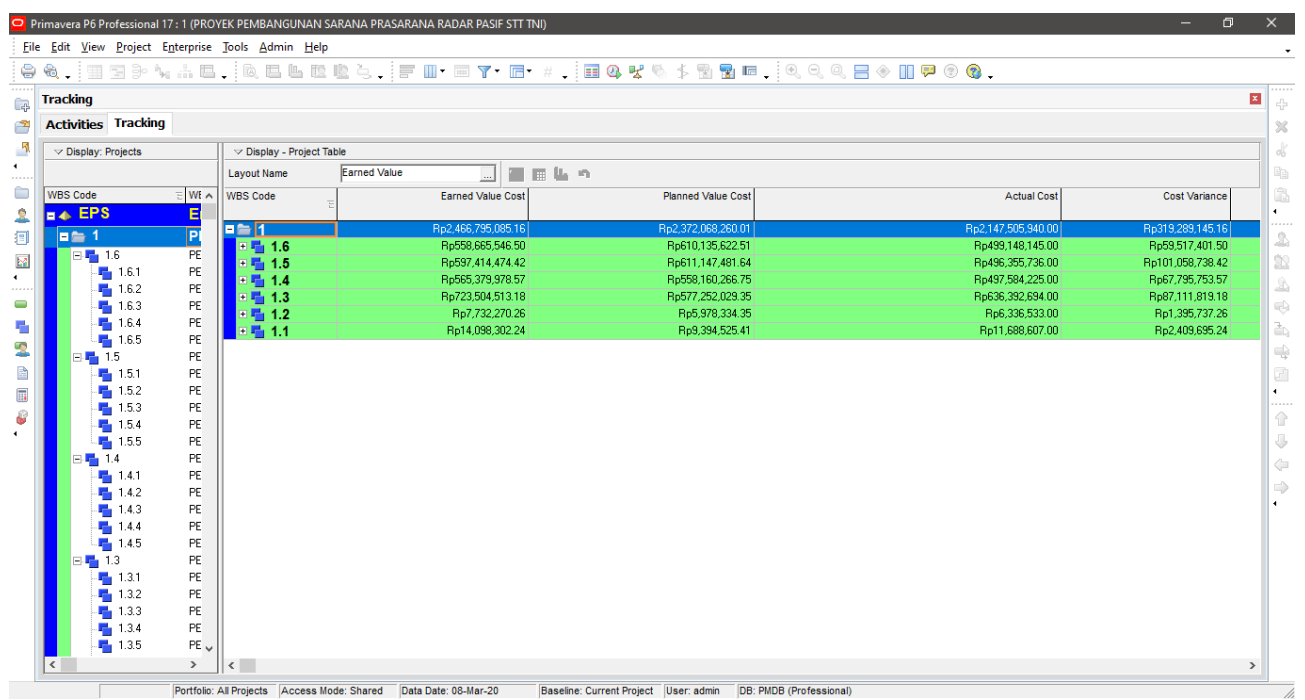

Gambar 3. Hasil indikator konsep nilai hasil pada minggu ke-8

Dari hasil analisis data yang dilakukan di dalam program Primavera P6, diperoleh indikator-indikator konsep nilai hasil yang didapat dari Laporan Proyek Pembangunan Sarana Prasarana Radar Pasif STT Natuna pada minggu ke8. Indikator-indikator tersebut adalah Actual Cost merupakan data pengeluaran di lapangan pada saat pelaporan 
pekerjaan, Planned Value Cost merupakan data RAB pada pekerjaan dan Earned Value merupakan nilai hasil yang didapatkan berdasarkan kinerja setiap aktivitas. Berdasarkan ketiga indikator konsep nilai hasil, didalam aplikasi Primavera P6 diperoleh kinerja pelaksanaan proyek yang ditunjukan pada Gambar 4 berikut.

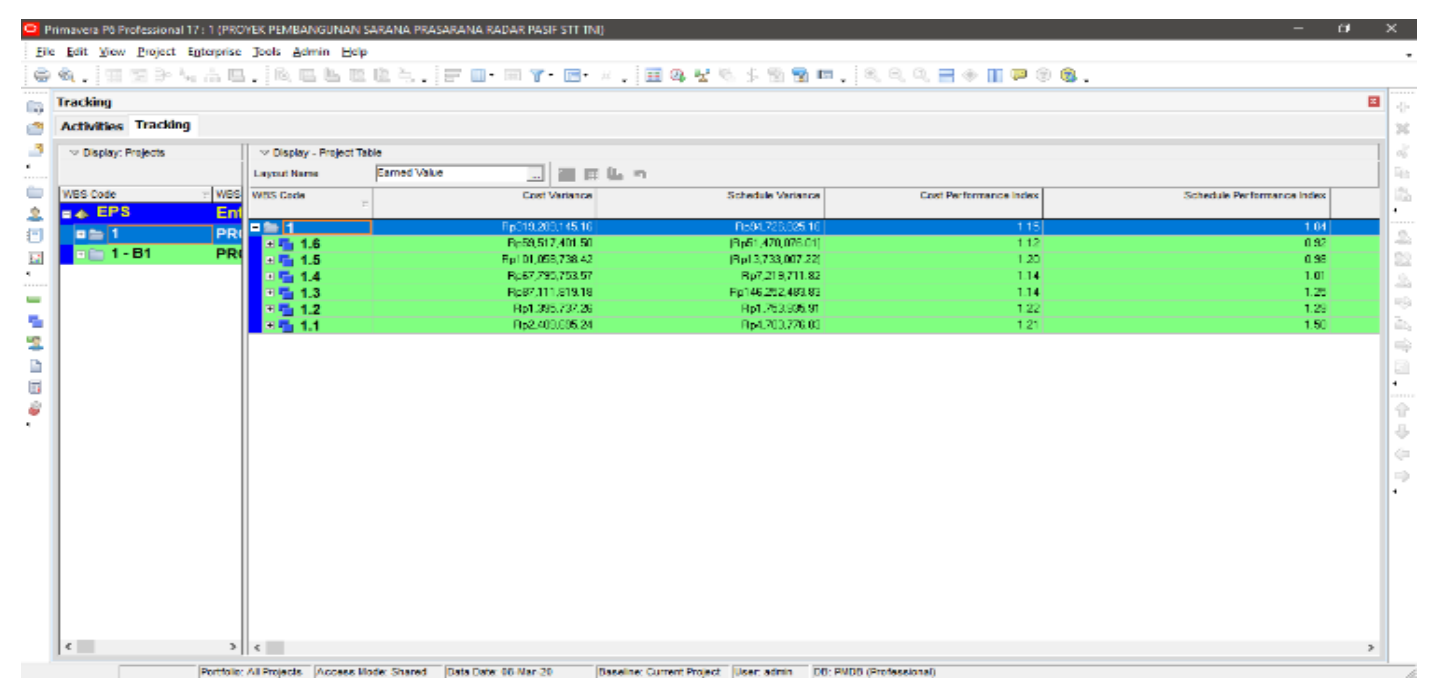

Gambar 4. Tracking kinerja pelaksanaan pada minggu ke-8

Hasil didalam program menunjukkan bahwa pada setiap item pekerjaan nilai dari ACWP lebih kecil dari BCWP atau Earned V alue yang berarti sampai minggu ke-8 biaya yang telah disalurkan didalam pekerjaan proyek lebih kecil dari anggaran, hal ini juga terlihat didalam jumlah Cost Variance (CV) yang nilainya positif dan dengan besaran Cost Performance Index (CPI) lebih dari satu. Sedangkan didalam segi waktu pelaksanaan kinerja didalam proyek mengalami perbedaan untuk setiap pekerjaan, seperti Pekerjaan Pembuatan Site Station II dan Pembuatan Site Station III yang mempunyai angka BCWP atau Earned Value lebih kecil daripada BCWS, yang menginformasikan bahwa pekerjaan tersebut berjalan lebih lambat dari jadwal yang direncanakan. Hal ini didukung dengan nilai Schedule Performance Index (SPI) yang kurang dari satu dan Schedule Variance (SV) yang bernilai negatif. Untuk keseluruhan Kinerja Pelaksanaan didalam proyek khususnya didalam segi waktu pelaksaan mendapatkan nilai yang positif karena mempunyai angka BCWP atau Earned V alue lebih besar daripada BCWS, yang mengindikasikan bahwa pekerjaan tersebut berjalan lebih cepat dari jadwal yang direncanakan

\section{Prakiraan Biaya Penyelesaian Proyek}

Tahapan ini dilakukan untuk mendapatkan output prakiraan biaya penyelesaian proyek dari program Primavera P6. Tahapan yang harus dilakukan adalah menambahkan Columns didalam tab Tracking dengan cara mengklik kanan di bagian header Column lalu klik Costumize. Pada tab Available Options klik pilihan Estimate at Completion Cost, Estimate to Complete, Variance at Completion dan Budget at Completion. Tahapan ini dilakukan sebanyak dua kali, pertama adalah untuk prakiraan biaya penyelesaian proyek di minggu ke-4 pada gambar 5 berikut. 


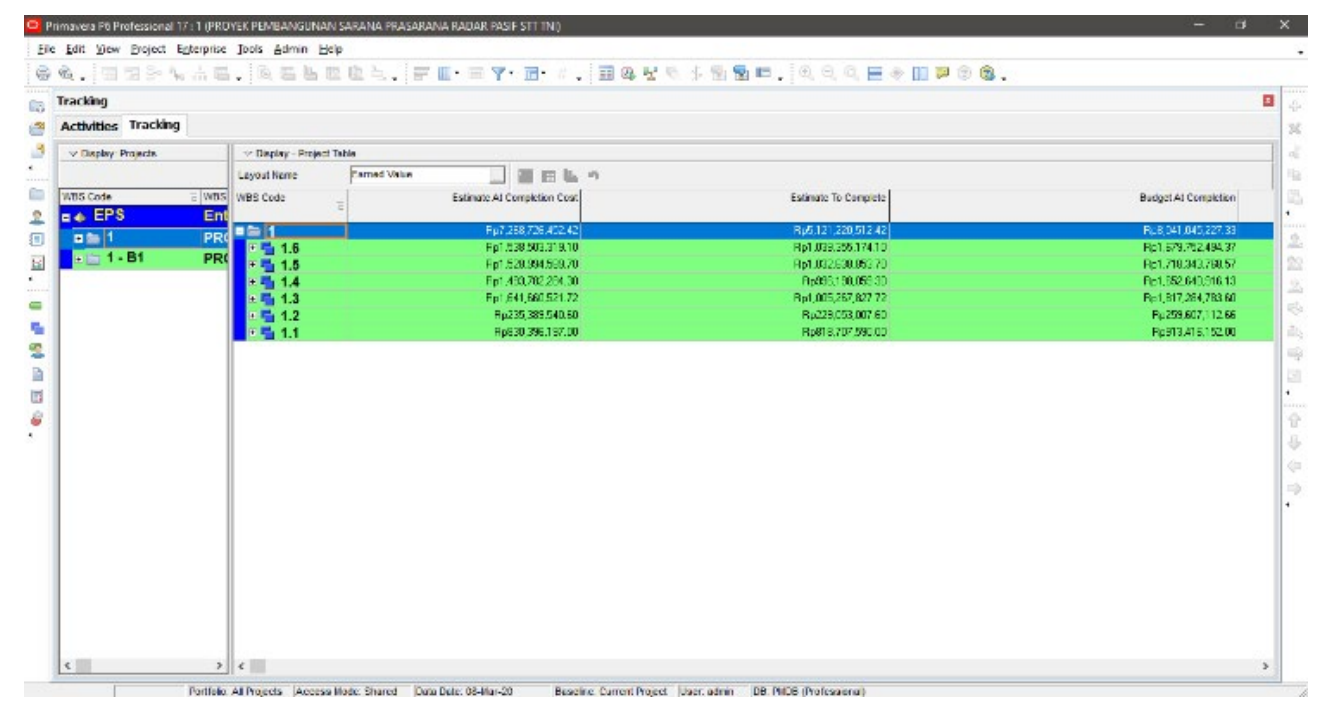

Gambar 5. Tampilan prakiraan biaya proyek pada minggu ke-4

Hasil didalam program menunjukan bahwa besarnya estimasi biaya saat penyelesaian(EAC) pada minggu ke-4 adalah Rp7.332.331.026.02 Angka ini lebih kecil apabila dibandingkan dengan rencana anggaran, yaitu sebesar Rp. Rp8.041.045.000,00 atau terdapat prediksi dari program Primavera P6 bahwa kontraktor akan mengalami selisih biaya proyek sebesar 8,7060\% jika kecenderungan kinerja yang ada pada saat pelaporan bertahan sampai akhir dari proyek tersebut. Besar keuntungan ini ditunjukan juga oleh program Primavera P6 dalam bentuk V ariance at Completion proyek sebesar Rp708.714.201,31. Tahapan kedua adalah untuk prakiraan biaya penyelesaian proyek di Minggu ke-8 pada gambar 6 berikut.

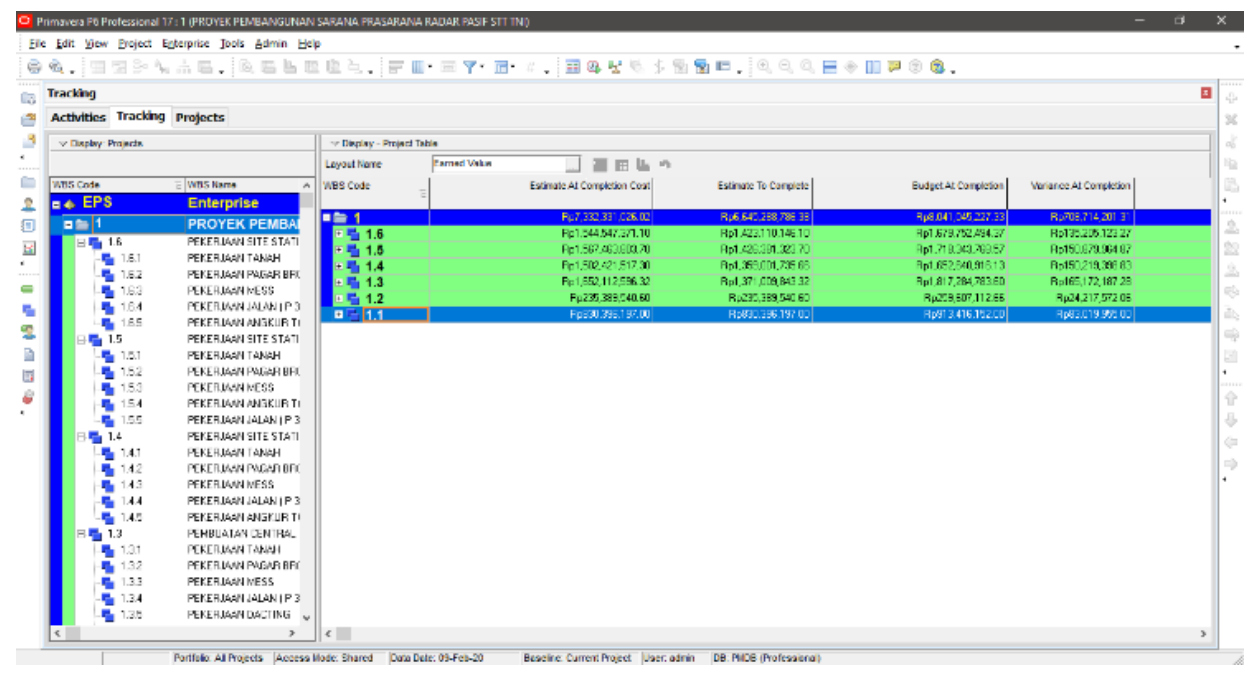

Gambar 6. Tampilan prakiraan biaya proyek pada minggu ke-8

Hasil didalam program menunjukan bahwa besarnya estimasi biaya saat penyelesaian (EAC) pada minggu ke-8 adalah Rp. 7.268.726.452,42 Angka ini lebih kecil apabila dibandingkan dengan rencana anggaran, yaitu sebesar Rp. Rp8.041.045.000,00 atau terdapat prediksi dari program Primavera P6 bahwa kontraktor akan mengalami selisih biaya proyek sebesar 9,4979\% jika kecenderungan kinerja yang ada pada saat pelaporan bertahan sampai akhir dari proyek tersebut. Besar keuntungan ini ditunjukan juga oleh program Primavera P6 dalam bentuk Variance at Completion proyek sebesar Rp. 772.318.774,91.

\section{Efektivitas Penerapan Analisis Konsep Nilai Hasil}

Pada perhitungan penyimpangan ini, penulis akan melakukan kalkulasi sederhana terhadap besaran simpang perbandingan antara estimasi biaya saat penyelesaian (Estimate at Completion) atau perkiraan biaya yang harus dikeluar- 
kan sampai berakhirnya proyek yang telah dihasilkan pada Analisis Konsep nilai hasil menggunakan program Primavera P6 dengan Actual Cost sampai proyek selesai. Pada perbandingan analisis konsep nilai hasil ini, nilai persentase yang didapatkan di minggu ke-4 dan ke-8 ber-urutan adalah 0,044\% dan 0,9113\%.

\section{SIMPULAN}

Berdasarkan hasil penelitian serta analisis data yang telah dilakukan, maka dapat disimpulkan bahwa,

1. Berdasarkan hasil progress pelaporan per tanggal 9 Februari 2020, estimasi besarnya biaya yang harus dikeluarkan kontraktor untuk pelaksanaan proyek sebesar Rp7.332.331.026,02 sedangkan berdasarkan progress pelaporan per tanggal 8 Maret 2020, estimasi besarnya biaya yang harus dikeluarkan kontraktor untuk pelaksanaan proyek sebesar Rp. 7.268.726.452,42

2. Berdasarkan hasil progress pelaporan per tanggal 9 Februari 2020, estimasi sisa biaya yang harus dikeluarkan kontraktor untuk penyelesaian sebesar Rp. 6.645.288.786,38 sedangkan berdasarkan hasil progress pelaporan per tanggal 8 Maret 2020, estimasi sisa biaya yang harus dikeluarkan kontraktor untuk penyelesaian sebesar Rp. 5.121.220.512,42

3. Jika tidak ada evaluasi kinerja pekerjaan pada proyek maka diproyeksikan kontraktor akan mengalami surplus atau selisih biaya positif dari anggaran sebesar Rp. 772.318.774,91 pada akhir proyek.

4. Berdasarkan analisis konsep nilai hasil pada progress pelaporan per tanggal 9 Februari 2020 ditemukan bahwa besar besar simpangan atau perbedaan terhadap perbandingan antara EAC (Estimate at Completion) atau perkiraan biaya yang harus dikeluarkan dengan Actual Cost sampai proyek selesai sebesar 0,044\% sedangkan berdasarkan analisis konsep nilai hasil pada progress pelaporan per 8 Maret 2020 ditemukan bahwa besar besar simpangan atau perbedaannya sebesar $0,9113 \%$. Karena besar penyimpangan yang kurang dari 1 persen, analisis konsep nilai hasil efektif dalam menentukan evaluasi kinerja dari proyek.

\section{REKOMENDASI}

Rekomendasi yang dapat diberikan pada penelitian berikutnya agar penelitian mengenai analisis konsep nilai hasil semakin baik adalah sebagai berikut:

1. Pada penelitian selanjutnya program Primavera P6 juga dapat digunakan untuk pengoptimalan jadwal dan biaya pada proyek.

2. Pada penelitian selanjutnya analisis dapat digunakan pada proyek yang belum selesai, sehingga hasil evaluasi kinerja menggunakan analisis konsep nilai hasil dapat diinformasikan kepada kontraktor pelaksa

\section{UCAPAN TERIMAKASIH}

Terima kasih penulis haturkan kepada Bapak Setiono, S.T., M.Sc.. dan Bapak Muji Rifai, S.T., M.T. sebagai dosen pembimbing yang sudah bersedia membimbing penulis dalam penelitian ini. Terima kasih juga penulis ucapkan kepada kedua orang tua, saudari, dan rekan penulis yang telah memberi dukungan hingga selesainya tugas akhir ini.

\section{REFERENSI}

Fajerin, Yan Anggita., 2010, “Analisis Konsep Nilai Hasil pada Proyek Rehabilitasi Rumah Sakit Ortopedi Surakarta dengan Menggunakan Program Primavera 6.0”, Skripsi. Surakarta : Universitas Sebelas Maret.

Icha, Tandoyo., Paulus, Sandra Lukito., 2013, "Perbandingan Aplikasi Program Microsoft Project dan Primavera dalam Penjadwalan Proyek Konstruksi”, Dumai : STT Dumai.

Indriyani., Izeul, Retno., 2015, "Metode Earned Value untuk Analisis Kinerja Biaya dan Waktu pelaksanaaan pada proyek pembangunan Condotel De Vasa Surabaya”, Skripsi, Surabaya : Institut Teknologi Sepuluh November

Kusuma, Doni Probo., 2016, "Pengendalian Biaya dan Waktu pada Proyek Pembangunan Hotel dengan Menggunakan Primavera Project Planner P6. Skripsi”. Surakarta : Universitas Sebelas Maret

Soeharto, Iman., "Manajemen Proyek dari Konseptual Sampai Operasional”, Jakarta: Penerbit Erlangga. 